\title{
Magdalena Kochmańska
}

Wydział Pedagogiczny

Uniwersytet Pedagogiczny im. KEN w Krakowie

\section{Rola samorządu małopolskiego w rozwoju przedsiębiorczości terytorialnej}

Przedsiębiorczość jest przede wszystkim postawą wobec życia. Aktywność obywateli w ich własnym środowisku jest głównym filarem społeczeństwa obywatelskiego. Z kolei gospodarka lokalna, tworząc niezależne od systemu władzy źródło wsparcia, przyczynia się do pobudzania aktywności lokalnej i ułatwia tworzenie harmonijnego systemu, w którym każdy członek społeczności ma możliwość odegrania swojej roli, wzrasta bowiem jego poczucie uczestnictwa.

$\mathrm{W}$ procesie zarządzania $\mathrm{w}$ samorządzie terytorialnym główna rola przypada władzom publicznym, które stanowią ośrodek decyzyjny, realizując określone funkcje regulacyjne w działalności społeczno-gospodarczej. W działalności samorządów terytorialnych centralne miejsce zajmuje kategoria interesu publicznego. Interesy własne mieszkańców i części jednostek gospodarczych są blisko związane z interesem publicznym, który realizuje się poprzez cele publiczne, związane z zaspokajaniem potrzeb zbiorowych wspólnoty samorządowej.

W literaturze podkreśla się, że samorządy terytorialne to złożone i trudne do zarządzania struktury, które działają w szybko zmieniających się i często nieprzewidywalnych warunkach, składających się na coraz większą liczbę czynników zmiennych. Są one miejscem, w którym władze odgrywają już wyraźnie rolę regulatora, a realizacja funkcji publicznych jest ich obowiązkiem niezbywalnym. Rolą władzy samorządowej, jako strategicznej i przedsiębiorczej, jest zatem ciągłe rozwiązywanie dylematów w zarządzaniu całym systemem (miasto, powiat, województwo) (Wojciechowski 2003, s. 11).

Standard życia mieszkańców jest w dużym stopniu funkcją jakości zarządzania przez władze lokalne i regionalne. Obserwując rozwiązywanie przez nie problemów, mieszkańcy dokonują politycznej oceny sprawności ich funkcjonowania, a jednocześnie aparatu administracji państwowej jako całości.

W warunkach decentralizacji sektora finansów publicznych ważną rolę w stymulowaniu i pobudzaniu przedsiębiorczości powinien odgrywać samorząd województwa. Zasadniczym jego zadaniem jest określenie strategii województwa i prowadzenie polityki intraregionalnej (Patrzałek 2003).

Prowadzenie polityki intraregionalnej oznacza podejmowanie przez samorząd wojewódzki działań dotyczących pozyskiwania i łączenia środków finansowych: publicznych i prywatnych, w celu realizacji zadań z zakresu użyteczności publicznej, utrzymania i rozbudowy infrastruktury społecznej i technicznej o znaczeniu regionalnym oraz tworzenia warunków rozwoju gospodarczego, przeciwdziałania bezrobociu i aktywizacji lokalnych i regionalnych rynków pracy.

Działalność samorządu województwa realizującego politykę wewnątrzregionalną cechuje dążenie do przełamywania barier strukturalnych i układów działowo-branżowych w gospodarce 
regionu. Podstawowym celem działań organów samorządu województwa jest wykorzystanie zasobów, którymi dysponuje region. Te zasoby to: przestrzeń (często niewykorzystana zarówno z punktu widzenia wielkości, jak i różnorodności), środowisko przyrodnicze, kapitał ludzki (wiedza, kwalifikacje, nowe umiejętności), dziedzictwo kulturowe i historyczne, infrastruktura, układ instytucjonalny oraz zasoby finansowe. Umiejętność dostrzeżenia tych elementów i połączenia ich jako aktywnych składowych danego terytorium w spójny układ wpisany w wizję globalną jest podstawowym zadaniem polityki wewnątrzregionalnej. Jego realizacja przyczynia się do kreowania nowych szans zatrudnienia i mobilizowania ducha przedsiębiorczości w regionie.

Politykę intraregionalną cechują partnerstwo i współpraca w układach:

- poziomym, poprzez stowarzyszenia i mobilizację na szczeblu regionu (gminy) rozmaitych czynników, podmiotów publicznych i prywatnych tam działających oraz polityki sektorowe;

- pionowym, poprzez włączanie przedsiębiorstw dużych, MŚP i innych partnerów oraz interwencji publicznych (międzynarodowych, krajowych) do zintegrowanego działania na rzecz danego terytorium.

Nawiązywanie współpracy i partnerstwa na skrzyżowaniu podejść „poziomego” i „pionowego”, z uwagi na ciągłe zmiany, ma charakter ewolucyjny. Mobilizacja zasobów i kompetencji w skali terytorium na rzecz strategii działania publicznego dokonuje się ciągle poprzez zmianę sposobów i metod interwencji publicznej oraz promocję nowych podejść, poglądów i działania.

Interwencja publiczna samorządu województwa w założeniach koncentruje się na:

- wspieraniu rozwoju opartego na zasobach i predyspozycjach regionu, a promowane przedsięwzięcia mają sprzyjać tworzeniu miejsc pracy odpowiadających potrzebom lokalnego i regionalnego rynku pracy. W tych działaniach korzysta się z myśli innowacyjnej środowisk regionalnych;

- pomocy publicznej, która jest kierowana głównie do małych i średnich przedsiębiorstw; zmniejszenie bezrobocia, szerzenie innowacyjności, osiąganie indywidualnych celów przedsiębiorcy i poprawa stanu zagospodarowania jednostek terytorialnych sprzyjają lepszemu zaspokajaniu potrzeb wspólnot samorządowych i rozwijaniu poczucia tożsamości terytorialnej.

Działania animacyjne samorządu województwa w celu pobudzenia regionalnej przedsiębiorczości oraz zmobilizowania zasobów i kompetencji w skali terytorium wymagają czasu. Rozwój regionu, uwarunkowany przez potencjał endogeniczny, nie odbywa się na rozkaz; tworzy się, buduje i wymaga ciągłego udoskonalenia sposobów interwencji publicznych na szczeblu terytorialnym poprzez promocję nowych podejść i nowych sposobów działania. Te modyfikowane interwencje samorządu powinny się koncentrować na:

- rozwoju kapitału ludzkiego, tzn. kierowaniu działań interwencyjnych publicznego sektora samorządowego na poprawę kwalifikacji lokalnej siły roboczej, dzięki czemu staje się ona atrakcyjniejsza dla przedsięwzięć wymagających wysoko wykwalifikowanych pracowników (szkolenia zawodowe, tworzenie i utrzymywanie miejsc pracy);

- rozwoju biznesu; mają one na celu: pobudzenie wzrostu zapotrzebowania na kadrę pracowniczą gminy, powiatu i województwa, przyciąganie biznesu z zewnątrz, rozwijanie istniejącego biznesu, popieranie innowacji i przedsiębiorczości;

- rozwoju infrastruktury technicznej; mają one na celu przede wszystkim rozbudowę i tworzenie nowej infrastruktury technicznej, dzięki czemu zmniejszają się koszty, które musiałby ponieść inwestor prywatny lokalizujący działalność w danym układzie terytorialnym. 
Instrumenty wspierania przedsiębiorczości w regionie mogą przybierać różne formy, zależnie od specyfiki obszaru. Najbardziej powszechne to: ułatwienia lokalizacyjne, ulgi, zwolnienia i umorzenia podatków gromadzonych przez budżet regionalny, pomoc w tworzeniu centrów pomocy małemu biznesowi, ośrodków przedsiębiorczości, innowacji i technologii oraz organizacja szkoleń i banków informacji. Samorząd województwa, wykorzystując te instrumenty oddziaływania na życie gospodarczo-społeczne regionu, może doprowadzić do zainicjowania i przyspieszenia procesu rozszerzania działalności gospodarczej na podległym obszarze.

Instrumenty oddziaływania samorządu województwa mają stwarzać podmiotom gospodarującym motywujące zachęty do prowadzenia działań uznawanych przez władze regionu za pożądane i uciążliwości w razie podejmowania i prowadzenia działań niepożądanych. Do tej grupy instrumentów mogą należeć instrumenty fiskalne, które powinny być dostępne władzom samorządu województwa. Mogą one polegać na przyznawaniu samorządom województwa prawa do nakładania podatków lub opłat publicznoprawnych lub na pozostawianiu pełnej swobody w kwestii ustalania stawek podatków i opłat będących źródłem dochodów budżetów województwa. Innym możliwym do zastosowania rozwiązaniem jest ustalanie udziału samorządu województwa w podatkach, które są dochodami budżetu państwa, czy przyznawanie samorządowi województwa uprawnień do ustalania dodatkowego procentu od stawek podatków, które są źródłem dochodów budżetu państwa.

Istotnym zagadnieniem odnoszącym się do oceny skuteczności potencjalnych instrumentów fiskalnych dostępnych władzom samorządu województwa jest problematyka struktury dochodów podatkowych samorządu województwa. Jeden z aspektów tej oceny powinien dotyczyć stopnia, w jakim - w odpowiedzi na wzrost aktywności gospodarczej w regionie - rosną dochody podatkowe budżetu województwa. Korzystne jest dobieranie i ustalanie takich źródeł dochodów podatkowych, które automatycznie reagują na zmiany w zatrudnieniu i aktywności gospodarczej w regionie (podatki dochodowe).

Dla zakresu i skuteczności oddziaływania samorządu na rozwój przedsiębiorczości (szczególnie średnich i małych przedsiębiorstw) ważne jest wypracowanie i ustalenie relacji między interwencją publiczną podejmowaną w ramach polityki gospodarczej rządu a polityką rozwoju regionów prowadzoną przez samorząd województwa. W wypracowaniu i ustaleniu tych relacji podstawowe znaczenie mają następujące kwestie:

- ustalenie klarownego i przejrzystego podziału odpowiedzialności władzy publicznej za identyfikację barier rozwoju przedsiębiorczości;

- ustalenie jasnego podziału zadań i środków publicznych związanych z oddziaływaniem na rozwój przedsiębiorczości oraz wykreowanie i dostosowanie do charakteru realizowanych działań struktur organizacyjnych instytucji;

- opracowanie procedur uruchamiania interwencji publicznych w sprawach o zasięgu ponadregionalnym, wymagających wsparcia władz krajowych;

- przyjęcie jasnych zasad i reguł współdziałania interweniujących podmiotów (samorząd województwa oraz rząd i jego agendy) w zakresie uruchamiania montażu finansowego związanego z finansowaniem interwencji publicznej w obszarze przedsiębiorczości.

Interwencja publiczna musi uwzględniać przepisy prawne Unii Europejskiej.

W miejsce dominacji układu resortowo-branżowego nad układem regionalnym ukształtowane i ustanowione miały być partnerskie relacje między sektorem rządowym a sektorem samorządowym, w których o procesach rozwoju województwa w głównej mierze decyduje jego samorząd. Po latach doświadczeń w funkcjonowaniu w Polsce samorządu regionalnego można zauważyć, że jest to w dużym stopniu utrudnione, gdyż dotychczas nie stworzono organom samorządowym odpowiednich warunków w zakresie dysponowania przez nie zróżnicowanymi i elastycznymi instrumentami polityki intraregionalnej. 
Podnoszenie innowacyjności regionów i budowanie regionalnych strategii innowacyjnych stało się wyzwaniem współczesnych czasów. W rozwoju innowacyjności regionów i skupionych $\mathrm{w}$ nich organizacji coraz ważniejszą rolę odgrywają sprawnie i profesjonalnie działające samorządy regionalne.

Jedną z poważniejszych barier rozwoju przedsiębiorczości w województwie jest niska innowacyjność gospodarki, która przejawia się m.in. w niewystarczającej działalności badawczo-rozwojowej związanej z przygotowaniem produkcji nowych i zmodernizowanych wyrobów, wdrażaniem nowych technologii i zakupem licencji. Niska innowacyjność gospodarki regionu spowodowana jest brakiem silnych podmiotów gospodarczych, zwłaszcza w branżach zaawansowanych technologii.

W warunkach zmian społeczno-ekonomicznych samorząd terytorialny w coraz większym stopniu staje się uczestnikiem społecznego procesu uczenia się i tworzenia wiedzy organizacyjnej wspólnoty lokalnej, świadomej konieczności przyspieszenia procesów rozwojowych. O sukcesie działań podejmowanych przez struktury samorządowe decydują dwa elementy:

- koordynacja rozwoju, współpracy, koegzystencji na poziomie wspólnoty;

- osiągnięcia poszczególnych jednostek.

W rozwoju innowacyjności regionalnej zasadnicze znaczenie mają regionalne strategie innowacji. Proces budowanie tych strategii jest oparty na otwartym dialogu pomiędzy przedstawicielami różnych grup i wykorzystuje w pełni specyficzną analizę aktualnej sytuacji społeczno-gospodarczej regionu oraz perspektywiczną wizję jego przyszłego rozwoju. Ten proces prowadzi do opracowania regionalnej strategii, która odpowiada na potrzeby środowisk biznesowych, szczególnie sektora małych i średnich przedsiębiorstw.

Regionalne strategie innowacji (RSI) są podstawowym narzędziem realizacji polityki innowacyjnej na poziomie regionalnym. Zgodnie z ustawą o samorządzie województwa, władze wojewódzkie są odpowiedzialne za rozwój społeczno-ekonomiczny regionu. Okres opracowania RSI w Polsce przypadł na lata 2000-2005. W tym czasie opracowano RSI w 15 regionach; strategie te zostały przyjęte przez sejmiki samorządowe poszczególnych regionów. Regionalne strategie innowacji stają się obecnie narzędziami realizacji polityki innowacyjnej w województwie. Są podstawą przekształceń społeczno-ekonomicznych w kierunku budowy gospodarki opartej na wiedzy; coraz większego znaczenia nabierają inwestycje w edukację, szkolenia, badania i innowacje, a tym samym rozwój przedsiębiorczości. Stanowią strategie rozwoju gospodarczo-społecznego i mają na celu stworzenie w poszczególnych regionach efektywnych systemów innowacyjnych, opartych na trwałym partnerstwie i współpracy pomiędzy przedsiębiorstwami, instytucjami naukowo-badawczymi, instytucjami otoczenia biznesu i administracją publiczną.

W literaturze przedmiotu podkreśla się: ,problematyka innowacyjności w regionach do czasu podjęcia prac nad regionalnymi strategiami innowacji była postawiona na marginesie analiz dokonywanych na potrzeby różnorodnych dokumentów strategicznych, w tym strategii rozwoju województwa" (Gorzelak 2006, s. 18).

Regionalne strategie innowacji stworzyły sytuację, w której zjawisko przedsiębiorczości oraz innowacyjności i procesy z nimi związane stały się przedmiotem dyskusji interesariuszy na poziomie regionalnym we wszystkich województwach. W województwach powołano zespoły badawcze zobowiązane do określenia poziomu innowacyjności sektora nauki oraz sfery przedsiębiorczości i otoczenia biznesu. Ponadto wykonano analizy i badania empiryczne, które w założeniu miały prowadzić do określenia celów polityki innowacyjnej na poziomie regionów popartych systemem wdrażania i monitoringu (Gorzelak 2006, s. 18). 
A. Tuziak pisze: „Od blisko 10 lat Komisja Europejska finansuje opracowanie regionalnych strategii innowacji w regionach Europy. Strategie takie zostały przygotowane w ponad 130 regionach krajów członkowskich Unii Europejskiej” (Tuziak 2006, s. 38).

Opracowanie RSI przyczyniło się do wzrostu znaczenia innowacji w wymiarze politycznym, do stworzenia trwałego partnerstwa między najważniejszymi instytucjami regionalnymi działającymi na rzecz innowacji i przedsiębiorczości oraz do budowania kultury innowacji. Proces budowania strategii oparty jest na otwartym dialogu między przedstawicielami różnych grup i wykorzystuje w pełni specyficzną analizę aktualnej sytuacji społeczno-gospodarczej regionu oraz perspektywiczną wizję jego przyszłego rozwoju. Proces taki prowadzi do opracowania regionalnej strategii, która odpowiada na potrzeby środowisk biznesowych, szczególnie sektora małych i średnich przedsiębiorstw.

Przy tworzeniu regionalnych strategii innowacji należy zwrócić uwagę na następujące zagadnienia:

- zewnętrzne uwarunkowania - żaden region nie funkcjonuje w izolacji, a proces jego rozwoju jest poddany wpływom globalnym i krajowym. Istotne są uwarunkowania międzynarodowe (w tym europejskie), ponieważ programy Unii Europejskiej (i związane z nimi fundusze UE) w znacznym stopniu wyznaczają zakres władz publicznych krajów należących do Unii Europejskiej; programy te są szansą na przełamanie względnej peryferalizacji krajów i regionów słabiej rozwiniętych, zarówno w sektorze badań naukowych, jak i pod względem zaawansowania technologicznego firm na tych obszarach funkcjonujących;

- diagnoza jest (w zasadzie) niezbędnym etapem prac nad strategią. Powinna wskazać przewidywane procesy rozwojowe regionu. Zakres diagnozy powinien być zgodny z tematyką strategii. Powinna ona obejmować wszystko to, co dla tematyki strategii jest istotne. Diagnoza powinna być uczciwa i oparta w głównie na charakterystykach jakościowych;

- sporządzenie wizji innowacyjnego potencjału regionu; pozwala to na nadanie wnioskom wynikającym z analizy diagnostycznej walorów ocen jakościowych;

- wobec powszechnego ograniczenia środków konieczne jest często dokonywanie trudnych wyborów. Jest ono w rzeczywistości istotą budowania strategii. Niewielka liczba celów daje świadectwo wyboru pewnych tylko kierunków działań i sprzyja percepcji strategii przez jej odbiorców (Grzelak, Jałowiecki 2000, s. 41-58).

Strategia innowacyjnego rozwoju regionu musi być ciągłym procesem, odpowiednio reagującym na zmieniające się potrzeby i oczekiwania przedsiębiorstw w zakresie innowacji i nie może zakończyć się wraz z opracowaniem dokumentu strategicznego. Jest to tylko początek długiej i trudnej drogi do osiągnięcia wymiernych prorozwojowych efektów. W strategiach rozwoju opracowywanych przez samorządy województw, a także gmin, miast, powiatów, będących wyrazem polityki rozwoju regionalnego, powinny się znaleźć cele ukierunkowane na pobudzanie przedsiębiorczości i innowacyjności małych i średnich przedsiębiorstw, mające istotny wpływ na rozwój regionu i skutkujące podnoszeniem poziomu życia jego mieszkańców.

Budując RSI, należy uwzględnić przede wszystkim następujące kwestie.

- Tworzenie kultury innowacyjnej. Rozwój systemu komunikowania się i informacji, działania informacyjne i szkoleniowe w zakresie wsparcia innowacyjnego podejścia w regionie. Stypendia dla najlepszych studentów szkół wyższych kształcących się na kierunkach istotnych z punktu widzenia regionalnych strategii innowacji. Doradztwo związane $\mathrm{z}$ tworzeniem sieci kooperacyjnych organizacji.

- Transfer wiedzy. Transfer wiedzy ze szkół wyższych i instytucji akademickich do organizacji poprzez staże absolwentów i pracowników w organizacjach. Doradztwo w zakresie 
innowacji i nowych technologii. Wspieranie powstawania firm innowacyjnych. Rozwój nowoczesnych form organizacji pracy i potencjału adaptacyjnego organizacji.

- Rozwój instytucji otoczenia biznesu. Wsparcie tworzenia sieci transferu innowacji i powiązań w zakresie RSI pomiędzy sferą nauki, organizacjami i innymi partnerami na szczeblu międzyregionalnym, regionalnym i lokalnym. Wsparcie agencji i stowarzyszeń rozwoju przedsiębiorczości oraz innych organizacji otoczenia biznesu. Rozwój infrastruktury parków naukowo-technologicznych. Dokapitalizowanie funduszy finansujących rozwój firm. Poprawa dostępności firm do źródeł finansowania innowacji.

- Wzrost konkurencyjności firm. Dostosowanie oferty usług doradczych do potrzeb firm. Wspieranie firm dokonujących nowych inwestycji, rozwoju MŚP i przedsiębiorstw dokonujących zakupu technologii i wartości niematerialnych (Tuziak 2006, s. 41-43).

Regionalne strategie innowacji powinny być zintegrowane i multidyscyplinarne. Ponadto, dla innowacji istotna jest nie tylko sama technologia; ważne są także: kapitał ludzki, badania i edukacja, kształcenie zawodowe, zarządzanie, finansowanie, marketing, polityka regionalna, edukacyjna, technologiczna i przemysłowa oraz konkurencja.

Jako przykład opracowania regionalnego strategii innowacji można podać Regionalną Strategię Innowacji Województwa Małopolskiego na lata 2005-2013. Przedstawia ona aktualny stan innowacyjności gospodarki i formułuje działania mające na celu uaktywnienie firm i innych organizacji, aby efektywniej wykorzystać potencjał innowacyjny regionu. Jest dokumentem wytyczającym drogi rozwoju woj. małopolskiego na lata 2005-2013 w kierunku zbudowania przedsiębiorczego i konkurencyjnego regionu. Powinny temu sprzyjać:

- restrukturyzacja tradycyjnych gałęzi przemysłu i kreowanie nowych, nie tylko w sektorze high-tech, lecz szczególnie w gałęziach nastawionych na wykorzystywanie naturalnego potencjału regionu i zarazem bezpiecznych dla środowiska;

- tworzenie sieci współpracy opartych na formalnych porozumieniach pomiędzy partnerami tworzącymi sieć;

- współpraca środowisk biznesowych ze sferą nauki i otoczenia biznesu;

- zwiększenie kultury organizacyjnej i innowacyjnej mieszkańców woj. małopolskiego;

- stworzenie preferencji dla rozwoju przemysłu służącego ochronie środowiska;

- powiązanie wszystkich gmin w sprawną sieć służącą całości regionu i przez to zapobieżenie marginalizacji niektórych ośrodków;

- włączenie w budowanie innowacyjnego regionu wszystkich uczestników kreowania innowacji: firm, instytutów naukowych, uczelni wyższych, ośrodków wsparcia (w tym szczególnie finansowego), administracji publicznej.

Wnioski wyprowadzone z diagnozy województwa pozwoliły nakreślić następujący obraz regionu:

- brak współpracy między instytucjami proinnowacyjnymi;

- stosunkowo niska innowacyjność gospodarki regionu;

- ograniczona współpraca biznesu z nauką (uczelniami wyższymi, instytutami naukowymi, ośrodkami naukowo-badawczymi);

- znacznie wyższa niż przeciętna aktywność na polu projektów i programów międzynarodowych. $\mathrm{Na}$ podstawie analizy strategicznej podczas budowy RSI stwierdzono, że w ocenie małopolskich przedsiębiorców najważniejszymi instrumentami wspierania małej i średniej przedsiębiorczości są: rozwój innowacyjności, wspieranie finansowe nowych inwestycji, udzielanie gwarancji w celu uzyskania pożyczek bankowych, tworzenie infrastruktury komunikacyjnej i informatycznej. Najniżej zaś oceniają oni takie instrumenty, jak: tworzenie ram 
organizacyjnych współpracy między organizacjami, procedury normalizacyjne i przyznawanie certyfikatów oraz tworzenie parków naukowo-technologicznych.

Największy wpływ na konkurencyjność firm będą wywierać:

- rozwój przedsiębiorczości,

- obniżenie stóp procentowych oraz dostępność finansowania bankowego,

- stabilność makroekonomiczna,

- zmniejszenie obciążeń podatkowych i składek ZUS,

- wzrost popytu pozwalający podwyższyć ceny sprzedaży własnych produktów.

Misję strategii zdefiniowano następująco: „Regionalna Strategia Innowacji Województwa Małopolskiego umożliwi zwiększenie poziomu innowacyjności i konkurencyjności firm, poprzez uaktywnienie ich współpracy z szerokim zapleczem instytucjonalnym w sferze nauki, prac badawczo-rozwojowych oraz transferu technologii”.

Sformułowano trzy cele strategiczne:

- podniesienie poziomu innowacyjności i przedsiębiorczości w województwie;

- wzmocnienie kontaktów sieciowych instytucji związanych z innowacyjnością regionu i lepsze wykorzystanie ich potencjału;

- wzrost znaczenia innowacyjności w polityce regionalnej i systemie kształcenia.

Sformułowane cele i zadania są w pełni adekwatne do potrzeb strategii rozwoju innowacji i przedsiębiorczości w Małopolsce.

System wdrażania strategii został oparty na istniejących instytucjach z główną rolą zarządu województwa i rady ds. innowacji oraz zespołów eksperckich. Sformułowano zasady regulujące funkcjonowanie RSI. Każde zadanie zostało przypisane konkretnej instytucji odpowiedzialnej za jego realizację. Określono szacunkowe wartości niezbędnych środków, wskazując także potencjalne źródła finansowania oraz stan zaawansowania (w przypadku zadań już realizowanych). Pośród źródeł finansowania wymieniono programy finansowane prze Unię Europejską.

Należy podkreślić, że niezbędne jest uzyskanie szerokiej społecznej akceptacji dla przyjmowanych rozwiązań strategicznych.

Zgodnie z ustawą o samorządzie województwa, przy formułowaniu strategii rozwoju samorząd województwa współpracuje z różnymi podmiotami, przy czym spośród możliwych partnerów społecznych i gospodarczych ustawa wskazuje w szczególności na jednostki samorządu lokalnego, samorząd gospodarczy i zawodowy, organizacje pozarządowe oraz szkoły wyższe i jednostki naukowo-badawcze.

Drugim ważnym obszarem działalności samorządu wojewódzkiego w rozwoju przedsiębiorczości jest strategia rozwoju woj. małopolskiego na lata 2007-2013. Strategia rozwoju województwa to ustalenie konkretnych celów tego rozwoju możliwych do osiągnięcia oraz metod realizacji zadań i zestawu środków, jakie zostaną wykorzystane do ich realizacji.

Kształtując strategię rozwoju woj. małopolskiego na lata 2007-2013 starano się w możliwie największym stopniu zachować:

- zasadę równości dostępu do informacji wszystkich zainteresowanych podmiotów. W tym celu materiały robocze, ekspertyzy, raporty z konsultacji, materiały konferencyjne i projekty dokumentów były na bieżąco publikowane na stronie internetowej oraz szeroko kolportowane;

- zasadę zrównoważenia przestrzennego i tematycznego prac nad projektem strategii. Stąd m.in. diagnozowanie stanu województwa i konsultacje w układzie powiatowym, spotkania i konsultacje środowiskowe, różnicowanie układu zespołów zadaniowych;

- zasadę równości szans udziału w procesie kształtowania strategii - zarówno równości szans kobiet i mężczyzn, jak i równości szans przedstawicieli różnych grup społecznych. 
Opracowując strategię rozwoju woj. małopolskiego, zwrócono uwagą na następujące zagadnienia:

- pielęgnowanie polskości oraz rozwój i kształtowanie świadomości narodowej, obywatelskiej i kulturowej mieszkańców, a także pielęgnowanie i rozwijanie tożsamości lokalnej;

- pobudzanie aktywności gospodarczej;

- podnoszenie poziomu konkurencyjności i innowacyjności gospodarki w województwie;

- zachowanie wartości środowiska kulturowego i przyrodniczego z uwzględnieniem potrzeb przyszłych pokoleń;

- kształtowanie i utrzymywanie ładu przestrzennego.

Głównymi autorami strategii rozwoju woj. małopolskiego byli lokalni liderzy, przedstawiciele instytucji społeczno-gospodarczych oraz działacze samorządowi i przedsiębiorcy. Nad procesem budowy strategii czuwali eksperci, którzy wykonali także analizy i przygotowali programy operacyjno-wdrożeniowe. W strategii założono współpracę samorządu województwa z partnerami zewnętrznymi jako konieczny warunek sukcesu strategii. Strategia będzie realizowana poprzez zadania:

- które pozostają w zasięgu bezpośrednich kompetencji przedsiębiorstw,

- na które województwo ma wpływ pośredni,

- na które województwo może się starać oddziaływać (np. przez kształtowanie opinii publicznej, lobbing czy rzecznictwo interesów).

Strategia rozwoju województwa na lata 2007-2013 jest oparta na czterech podstawowych zasadach: partnerstwa, zarządzania strategicznego rozwoju województwa, autonomii programowej małopolskiej strategii rozwoju regionalnego, rozwoju zrównoważonego. W strategii wojewódzkiej uwzględniono trzy zasadnicze cele strategiczne:

- wzmocnienie konkurencyjności gospodarczej województwa (cel A);

- stworzenie warunków dla wszechstronnego rozwoju społecznego i wysokiej jakości życia (cel B);

- wzmocnienie potencjału instytucjonalnego województwa (cel C).

Aby sprostać współczesnym wymaganiom gospodarki, cel pierwszy (A) obejmuje cztery obszary polityki rozwoju, które są kluczowymi dla efektywnej realizacji strategii. Należą do nich: pierwszy obszar - społeczeństwo wiedzy i aktywności, drugi obszar - gospodarka regionalnej szansy, trzeci obszar - infrastruktura dla rozwoju regionalnego, czwarty obszar - Krakowski Obszar Metropolitalny.

W obszarze społeczeństwa wiedzy i aktywności przewiduje się działania zmierzające do poprawy jakości i poziomu wykształcenia mieszkańców, rozwoju społeczeństwa informacyjnego, które będzie motorem napędzającym poprawę życia mieszkańców Małopolski, oraz wspierania rozwoju indywidualnej przedsiębiorczości, rozwoju rynku pracy.

W ramach obszaru gospodarka regionalnej szansy przewiduje się działania ukierunkowane na: wsparcie międzynarodowej konkurencyjności małopolskich przedsiębiorstw i instytucji, rozwój innowacji oraz nowoczesnych technologii, przyciąganie bezpośrednich inwestycji do regionu. W ramach obszaru infrastruktura dla rozwoju regionalnego przewidziano: rozwój infrastruktury dla społeczeństwa informacyjnego oraz kompleksowe zagospodarowanie strefy aktywności gospodarczej. W obszarze czwartym przewiduje się umocnienie europejskiej pozycji Krakowskiego Obszaru Metropolitalnego i rozwój funkcji metropolitalnych. Działania będą dotyczyć: wsparcia organizacyjnego i finansowego podczas tworzenia i rozwoju placówek akademickich i naukowo-badawczo-produkcyjnych, wsparcie rozwoju firm stosujących technologie przyjazne dla środowiska. 
Drugi cel strategiczny (B) - stworzenie warunków dla wszechstronnego rozwoju społecznego i wysokiej jakości życia - składa się z trzech obszarów: obszar piąty - spójność wewnątrzregionalna, obszar szósty - ochrona środowiska oraz obszar siódmy - dziedzictwo i przestrzeń regionalna. Zamierzenia zawarte $\mathrm{w}$ tej części strategii to dążenie do zminimalizowania wewnętrznego zróżnicowania w regionie, tak aby w żadnej części województwa nie dochodziło do regresu i pogorszenia sytuacji społeczno-gospodarczej i warunków życia ludności. Istotne działania w tej części strategii rozwoju Małopolski to integrująca polityka społeczna mająca głównie za zadanie wyrównywanie szans osób niepełnosprawnych oraz poprawę kondycji małopolskiej rodziny dzięki inicjatywom organizacji pozarządowych. Inne bardzo ważne zadania to ochrona zasobów wodnych, ochrona powietrza i zwiększenie wykorzystania niekonwencjonalnych źródeł energii oraz gospodarowanie odpadami w taki sposób, aby minimalizować ilość wytwarzanych odpadów oraz wprowadzić zgodnie z normami europejskimi sposoby ich odzysku i unieszkodliwiania, co wiąże się m.in. $z$ modernizacją składowisk odpadów niespełniających wymogów ochrony środowiska. W ramach drugiego celu strategicznego przewiduje się również działania ukierunkowane na ochronę i kształtowanie krajobrazu kulturowego, aby zachować jego najważniejsze walory, oraz rewitalizację obszarów zdegradowanych.

Trzeci cel strategiczny (C) stanowi wzmocnienie potencjału instytucjonalnego województwa. Obejmuje dwa obszary polityki rozwoju. Są to: współpraca terytorialna (obszar ósmy) oraz nowoczesne zarządzanie publiczne (obszar dziewiąty).

Sposób realizacji strategii rozwoju województwa w dużej mierze zależy od profesjonalizacji administracji publicznej. Jakość administracji i zarządzania publicznego, którą winny cechować sprawność oraz chęć uczenia się i współpracy, jest jednym z decydujących wewnętrznych czynników rozwoju regionu. Mądre, kompetentne i otwarte władze publiczne są niezbędnym warunkiem wykorzystania szans rozwojowych, jakie obecnie (jako członek UE) mają Polska i region. Szczególna potrzeba doskonalenia pracy administracji publicznej wynika z konieczności podnoszenia jej zdolności absorpcyjnych w zakresie środków strukturalnych przeznaczonych i kierowanych na wspieranie polityki rozwoju regionalnego. Te wyzwania uzasadniają podejmowanie działań nastawionych na trwały rozwój, uzależniony również w coraz większym stopniu od bogactwa i umiejętności wykorzystywania różnych sytuacji. Nie dotyczy to tylko sfery gospodarczej, ale właściwie wszystkich możliwych obszarów funkcjonowania regionu. Innymi słowy, im mniejszy dystans instytucjonalny, tym więcej zrozumienia; im więcej zrozumienia, tym większa szansa na efektywną współpracę.

W ramach obszaru ósmego przewiduje się działania ukierunkowane na: promocję i wzmocnienie pozycji Małopolski na arenie krajowej i międzynarodowej, rozwój współpracy międzyregionalnej celem osiągnięcia standardów najlepszych regionów europejskich oraz promocję wewnątrzregionalną i wzmocnienie potencjału partnerów z Małopolski do uczestnictwa we współpracy międzyregionalnej i budowie zdolności instytucjonalnej administracji małopolskich partnerów.

W ramach obszaru dziewiątego strategii rozwoju woj. małopolskiego przewidziano działania powodujące:

- podniesienie sprawności działania urzędów administracji publicznej poprzez zastosowanie nowoczesnych narzędzi rozwoju instytucjonalnego, benchmarkingu administracyjnego;

- systemowe doskonalenie kwalifikacji pracowników małopolskiej administracji publicznej;

- doskonalenie urzędów $\mathrm{w}$ załatwianiu spraw oraz $\mathrm{w}$ dostępie do informacji publicznej poprzez stosowanie ,e-administracji”;

- stworzenie zaplecza merytorycznego dla polityki rozwoju województwa w celu przyczynienia się do podniesienia jakości i skuteczności polityki rozwoju regionalnego. 
Podstawowym źródłem finansowania strategii rozwoju woj. małopolskiego w latach 2007-2013 będą:

- środki krajowe pochodzące: z budżetu państwa, od jednostek samorządu terytorialnego, z funduszy celowych;

- środki pochodzące z instrumentów finansowych Unii Europejskiej, szczególnie fundusze strukturalne.

Każdemu obszarowi działania strategii rozwoju woj. małopolskiego przyporządkowano odpowiednie środki finansowe.

Reasumując, przedstawione dwa podstawowe obszary działań samorządu województwa małopolskiego: regionalne strategie innowacji i strategie rozwoju województwa, jak się wydaje, w istotny sposób mogą się przyczynić do dynamicznego rozwoju przedsiębiorczości w województwie.

\section{Literatura}

1. Gorzelak G. i in., 2006, Polskie Regionalne Strategie Innowacji. Ocena i wnioski do dalszych działań, Ministerstwo Rozwoju Regionalnego, Warszawa.

2. Gorzelak G., Jałowiecki B., 2000, Metodologiczne podstawy strategii rozwoju regionu na przykładzie województwa lubuskiego, „Studia Regionalne i Lokalne”, z. 3.

3. Patrzałek L., 2003, Samorząd województwa a rozwój małej i średniej przedsiębiorczości, Część pierwsza. Podstawowe determinanty rozwoju przedsiębiorczości w latach 2002-2003. Zeszyt Naukowy pod red. Janusza Ostaszewskiego, Warszawa, kwiecień-maj 2003.

4. Tuziak A., 2006, Innowacje a proces rozwoju regionalnego [w:] Innowacyjność i rozwój, A. Tuziak (red.), Wyd. U Rz. Rzeszów

5. Wojciechowski E., 2003, Zarządzanie w samorzadzie terytorialnym, Difin, Warszawa.

\section{The Role of the Local Government in Malopolska Region in the Development of Territorial Entrepreneurship}

The article describes the entrepreneurship and the factors in its development. The responsibilities of local authorities for the development of entrepreneurship were indicated. Two aspects of the local governmental activity for the development of entrepreneurship in Malopolskie Province were described in detail, i.e. the regional strategy for innovation and strategy for the development of the province. 